\title{
The national map of Japan compiled by the Tokugawa Shogunate
}

\author{
Hirotada Kawamura * \\ kawa-503@gaea.ocn.ne,jp \\ * Corresponding author
}

Keywords: Provincial map, so-called Keicho map of Japan, Revolt of Shimabara, Administrative inspector

\begin{abstract}
:
In early modern Japan, it was a political tradition for the central government to compile a national map. Edo Shogunate had compiled nationally the nihon-sōzu (national map of Japan) from the kuni-ezu (provincial map). The Shogunate government ordered the major Daimyōs (feudal lords) of each kuni (province) to produce personally their own kuni-ezu (provincial maps), and present it to the Shogunate. Then the government compiled nationally the map of Japan from those provincial maps, which were consists of 68 pieces of all kuni traditionally in Japan.
\end{abstract}

Each Shogunate national map of Japan was a huge chromatic hand writing map. For a considerable time, the national map created by the Shogunate government was mistakenly believed to have been produced total of four times (during the Keichō, Shōhō, Genroku, and Kyōhō eras) in all. This is because it was generally known that the Shogunate government collected provincial maps from each province in all these eras.

By the way, recently it was revealed in my study that the national maps created by the Tokugawa Shogunate during the Edo era 260 years (1608-1867) was six times in all, as shown in Table 1, except for the last Ino's map. Ino's map was not compiled from kuni-ezu and the making of this map had a big personal role rather than work of the government. Therefore, in this report, it has not taken up about the Ino's map.

It was assumed that the Keichō era's national map was based on its provincial map. However, it is now a general view that Keichō era's provincial map not created nationwide but having been created only in western part of Japan with many lords promoted by Toyotomi Hideyosi. This raises an important question; how can a national map be correctly produced if all provincial maps in Japan are not included?

On the other hand, the third shogun Tokugawa Iemitu sent Junkenshi (Administrative inspectors) to all provinces for the first time in 10th year of Kan'ei (1633), and each inspector collected provincial maps from their respective province and then the Shogunate government compiled the national map of Japan for the first time in the Edo period. Its copy remains nowadays in four places, including the Saga prefectural Library.

The Revolt of Simabara occurred four years after the first national map of Japan was made, and Shogunate government had difficulty in dispatching armies to distant Kyūshū. Not only was strongly aware of the lack of traffic information in the previous map, but the 3-disc set map was too large for usable. From that reflection, Inoue Masashige, the chief officer of the government hurriedly thought about the revision of the national map, and collected the provincial maps again only from the Chūgoku district leading to kyūshū and quickly reproduced the map. That is the map of 15 years of Kan'ei.

Table 1 Projects to compile national map of Japan under the Tokugawa Shognate

\begin{tabular}{|c|l|c|c|}
\hline & \multicolumn{1}{|c|}{ Name of map } & $\begin{array}{c}\text { Start year of } \\
\text { the project }\end{array}$ & $\begin{array}{c}\text { Year of } \\
\text { Completion }\end{array}$ \\
\hline 1 & Kan'ei 10 & 1633 & ca.1635 \\
\hline 2 & Kan'ei 15 & 1638 & 1638 \\
\hline 3 & Shoho the first & 1644 & ca.1651 \\
\hline 4 & Shoho the second & 1669 & 1669 \\
\hline 5 & Genroku & 1697 & 1702 \\
\hline 6 & Kyoho & 1717 & 1725 \\
\hline 7 & Ino's & 1800 & 1821 \\
\hline
\end{tabular}



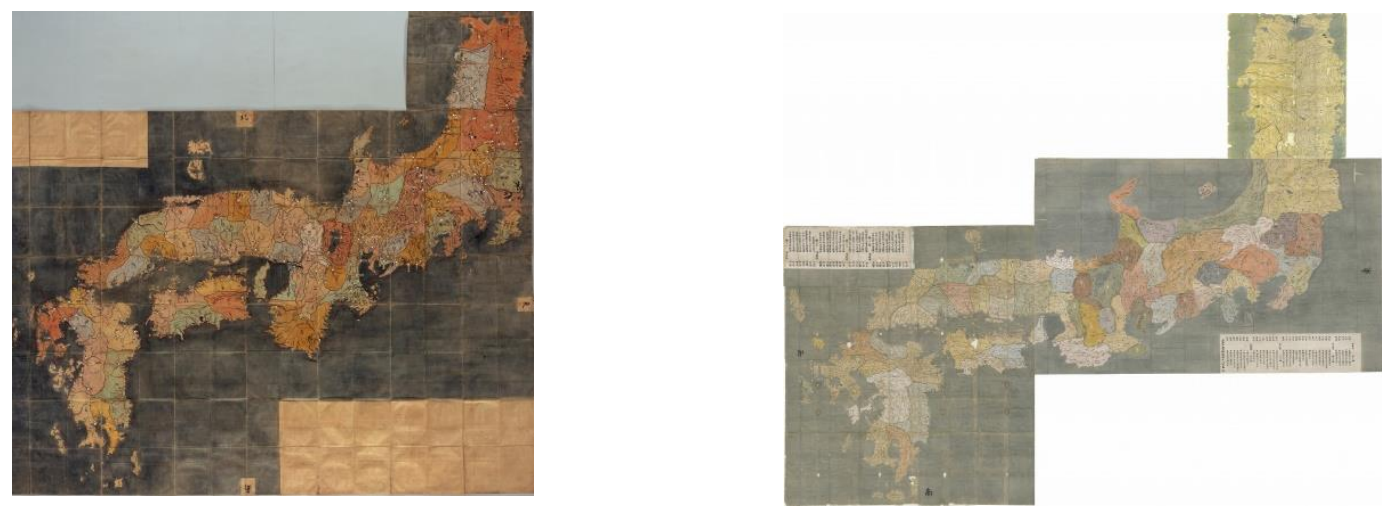

Figure 1. Two types of national map of Japan in Edo early days. The figure on the left is the so called "the Keicho map of Japan"which is held by the National Diet Library. The figure on the right is a three sheet of map in held by the Saga Prefectural Library.

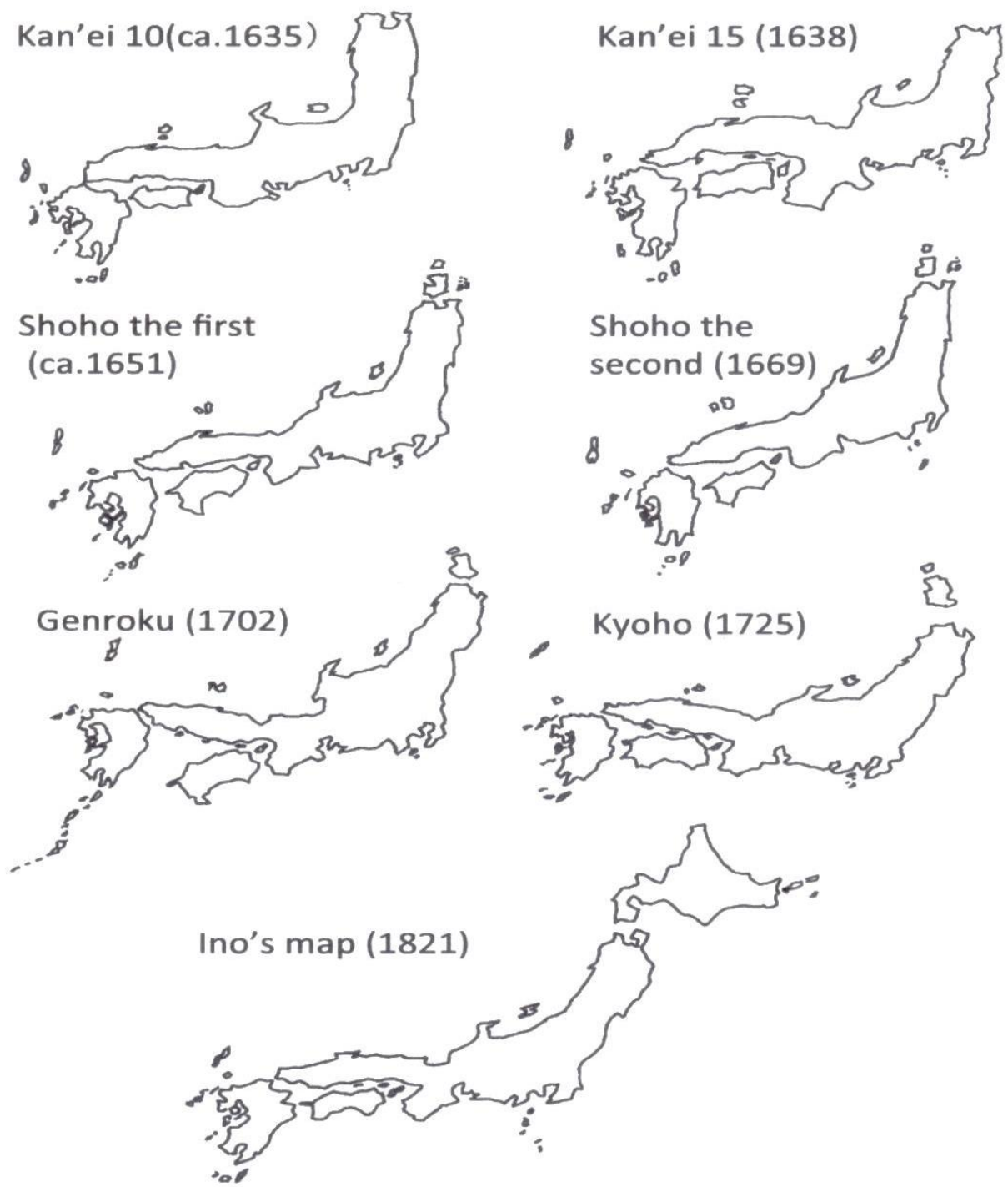

Figure 2 The figure changes national maps of Japan by the Tokugawa Shogunate 